Article

\title{
Relationship between Corporate Social Responsibility and Financial Performance in the Mineral Industry: Evidence from Chinese Mineral Firms
}

\section{Xiping Pan ${ }^{1,2, *}$, Jinghua Sha ${ }^{1,2, *}$, Hongliang Zhang ${ }^{1,3}$ and Wenlan Ke ${ }^{1,2}$}

1 School of Humanities \& Economic Management, China University of Geosciences,

Beijing 100083, China; E-Mails: zhanghongliang@swust.edu.cn (H.Z.); kewenlan1988@hotmail.com (W.K.)

2 Key Laboratory of Carrying Capacity Assessment for Resource and Environment, Ministry of Land and Resource, Beijing 100083, China

3 School of Economics and Management, Southwest University of Science and Technology, Mianyang 621010, China

* Authors to whom correspondence should be addressed; E-Mails: panxp1234@outlook.com (X.P.); shajinghua@outlook.com (J.S.); Tel.: +86-10-8232-3059 (J.S.); Fax: +86-10-8232-1783 (J.S.).

Received: 20 March 2014; in revised form: 26 May 2014 / Accepted: 13 June 2014 /

Published: 30 June 2014

Abstract: This paper examines the relationship between Corporate Social Responsibility (CSR) and Corporate Financial Performance (CFP) using panel data for 228 Chinese mineral listed firms from 2010 to 2013 with Pooled Least Squares regression analysis. Our study considers five different sublevel CSR issues - shareholder responsibility, employee responsibility, environmental responsibility, public responsibility, and supplier, customer and consumer responsibility - in capturing the effects of CSR elements on CFP. The estimation results show the different effects of each sublevel CSR issue on CFP. Overall, shareholder, employee responsibility, environmental responsibility, supplier, customer and consumer responsibility have significant relationships with CFP, which are the stakeholders who have the closest linkage with firm operations. Meanwhile, public responsibility outside the firm does not show significant interaction with CFP, which is why many mineral firms ignore the public interest and this leads to conflicts. Shareholder responsibility has the most significant positive effect on CFP. Supplier, customer and consumer responsibility and environmental responsibility usually have negative effects on CFP as costs increase. Moreover, all 228 listed mineral firms that were selected in this paper have been classified into five sub-sectors: the extractive industry, metal fabrication 
industry, oil and gas industry, gas and water-related industry, and oil-producing equipment industry, based on the Industry Classification Benchmark (ICB). Our study shows that the differences in the relationship between CSR and CFP for five sublevel industries are due to industry characteristics. If the government wants to solve these conflicts and positively encourage firms to adopt CSR, it is necessary to create a mining development environment whereby firm profits are closely tied to CSR.

Keywords: corporate social responsibility; corporate financial performance; Chinese mineral firms; relationship

\section{Introduction}

The mineral industry experienced a huge boost over the last decade with mining output increasing 5.6 times during the 2002-2011 period [1]. However, accompanying this rapid growth was a lack of Corporate Social Responsibility (CSR), the presence of externalities, and many social conflicts, such as environmental pollution, security issues, employment of local residents, and illegal land use. All of these conflicts are closely associated with stakeholder interests. In recent years, the stakeholders of firms such as shareholders, employees, investors, governments, local communities, trading partners, consumers, and non-governmental organisations are conscious of their interests and corporate management. This directly or indirectly influences a firm's financial performance [2]. In China, for example, many mineral enterprises have been shut down because of their significant environmental pollution and substandard security. At the present time, management usually ignores the stakeholder benefits outside the firms (such as the community and public) because the companies do not have an interest in adopting CSR spontaneously unless they could receive financial benefits. CSR is just a guise to cope with government regulation and fawn on the public. This phenomenon is also common in the minerals sector of some natural resources-rich areas such as Ghana and sub-Saharan Africa where companies have little sense of who to target in their local economic development policies, and programs lead to conflicts and scrambles $[3,4]$.

To solve mineral conflicts and to maintain the sustainable development of the Chinese mineral industry as well as social harmony, minerals firms must adopt CSR ideas. Milton Friedman argued that it is the firm's nature to pursue its interests and that the social responsibility of a business is to increase its profits [5]. To solve this problem, it is important to ask whether CSR has effects on Corporate Financial Performance (CFP) in the Chinese mineral industry. This paper aims to answer this question.

In previous studies, scholars sought to find the linkage between CSR and CFP. The earliest study of this subject began in the 1970s [6-10], came of age in the 1980s [11], and has continued in recent years. However, even in recent years, the empirical research has not arrived at a consensus. There have been different results about the relationship between CSR and CFP. The different opinions are mainly sorted into three types: positive, negative, and neutral. Vance found that firms considered to have good CSR performance may not do well in the stock market, and his research shows that CSR and return of equity (ROE) have a negative relationship [10]. Some studies also find that if managers pursue their own interests, they may sacrifice the interests of shareholders and stakeholders [12-14]. Related 
opinions that hold that the two have a negative relationship argued that managers pursuing CSR will come into conflict with value maximisation [15]. Blowfield found there is usually a neutral and negative correlation between social or environment issues and companies' business performance. This situation is even more so in developing countries [16,17]. The idea that business is an agent to solve international development problems such as poverty is insufficient and unjustified [18]. Frynas argues that private firms are unlikely to act as successful development actors without corporate governance reforms, which would align the interests of non-traditional stakeholders with corporate interests [19]. There are fundamental problems surrounding the capacity of private firms to deliver development and the aspiration of achieving development through Corporate Social Responsibility (CSR) based on the evidence from multinational oil companies [20]. Scholars holding the neutral relationship opinion said that the two do not have a significant interaction because profits from socially responsible conduct will compensate for the cost in market equilibrium. The linkages are quite complex. Some academic research shows that a social orientation does not have any linkage with the firm's financial performance [21]. Most empirical studies' results support the positive relationship hypothesis, and the opposing research is usually based on a country or region [22-25].

In recent years, the new research direction for the relationship between CSR and CFP has been detailed in specific industries and specific CSR elements. Industry specialisation includes the financial industry (banking industry), petroleum-gas industry, information technology industry, and restaurant industry [26-30]. This trend may be due to fast development within these industries during recent years, which caused conflicts among stakeholders and attracted public attention. The second research innovation in this field is that scholars began to find relationships between CFP and a specialised CSR element such as employee and supply chain responsibility. Lee et al. studied the relationship between employee rights protection and CFP and stated that both buyer and supplier should adopt employee rights protection to improve their corporate reputation and financial performance [31]. Wang found that financial benefits are associated with environmental and social supply chain management activities [32]. Some scholars found that environmental issues interact with CFP [2,33,34]. There is also some research focused on moderate roles such as ownership, institutional difference, or R\&D on the relationship between CSR and CFP [35-37]. Meanwhile, we have not found previous studies that capture empirical research on the linkage between CSR and CPF specific to the minerals industry.

This paper aims at complementing the existing literature by explicitly studying the relationship between CSR and CFP in the Chinese mineral industry using the panel data of 228 listed mineral firms from 2010 to 2013 with Pooled Least Squares regression analysis. In this paper, there are four main goals we want to achieve. First, this study adopts well-established techniques in a systematic matter using the Pooled Least Squares regression method to find the relationship between CSR and CFP, instead of a qualitative judgment. Second, we try to find the relationships between CSR elements and CFP. In this paper, CSR is composed of shareholder responsibility, employee responsibility, supplier, customer and consumer responsibility, environmental responsibility, and public responsibility based on stakeholder theory. Third, all 228 listed mineral firms selected have been classified into five sub-sectors: the extractive industry, metal fabrication industry, oil and gas industry, gas and water-related industry, and oil-producing equipment industry based on the Industry Classification Benchmark (ICB). This research will find the different relationships between CSR and CFP among the five sub-sectors. Fourth, we try to find measures to solve Chinese mineral industry conflicts from the financial scope which are different from other measures such as legislation and supervision. 
The structure of the remainder of this paper is as follows. Section 2 introduces the data. Section 3 introduces the measures and methods. The empirical results and discussion are reported in Section 4. Finally, there is a brief conclusion.

\section{Data}

CSR performance and financial performance are taken from a Chinese professional financial services website named HEXUN, which is specialised for high-end investors in China.

The data on CSR performance come from the open online Corporate Social Responsibility Database released by HEXUN. It is the only available data source we could obtain that covers the evaluation and ranking of CSR performance on all of the listed companies in China. The details of the evaluation method used by HEXUN can be seen in Appendix A. The CSR performance evaluation on the website is based on the annual financial report and CSR report of each firm released by the Shanghai stock exchange and Shenzhen stock exchange.

The financial performance data come from the HEXUN online financial ratio database based on each firm's Annual Financial Report. We chose five different financial indicators for CFP that include both accounting-based data and market-based data. The indicators will be introduced in the Measures section. More details can be seen in Appendix B.

We chose all data from the HEXUN website for two reasons: first, it is the only data source we could obtain that covers all Chinese listed mineral firms' CSR performance. Second, all of the data come from the same source and all of these firms' data are calculated in the same way, which ensure the data's consistency and comparability.

We have used all available data in the initiation of this study. This paper yields 228 firms (the details can be seen in Table B2) or 912 firm-years; a total of 9273 data points. Table 1 shows the descriptive statistics of each variable. It appears that there is a wide diversity in the firms and no trend in the variables. This suggests that there is ample scope for analysis and that, apart from looking into the overall data, the sub-level variables seem promising.

Table 1. Descriptive statistics.

\begin{tabular}{lcccccccc}
\hline & Mean & Median & Maximum & Minimum & S.D & Skewness & Kurtosis & Observations \\
\hline CSR & 30.557 & 21.12 & 85.77 & -4.25 & 20.55 & 0.791834 & 2.216253 & 826 \\
Shareholder-R & 12.899 & 13.49 & 20.47 & -8.25 & 4.388 & -0.86577 & 3.90468 & 826 \\
Employee-R & 4.6102 & 2.545 & 15 & 0 & 4.678 & 0.93961 & 2.393785 & 826 \\
Supply chain-R & 3.6392 & 0 & 20 & 0 & 5.654 & 1.063599 & 2.438038 & 826 \\
Environmental-R & 5.4903 & 0 & 30 & 0 & 8.625 & 1.113649 & 2.584567 & 826 \\
Public-R & 3.9184 & 4.17 & 15.79 & -10 & 3.015 & -0.255342 & 5.332701 & 826 \\
ROE & 0.0381 & 0.07 & 3.1 & -20.7 & 0.809 & -22.04669 & 543.3537 & 826 \\
ROA & 0.0398 & 0.03 & 0.88 & -1.09 & 0.075 & -1.875569 & 84.7509 & 826 \\
EPS & 0.3766 & 0.27 & 3.73 & -1.69 & 0.545 & 1.388215 & 9.541381 & 826 \\
MB & 0.3551 & 0.16 & 50.3 & -0.72 & 2.252 & 19.04598 & 389.9247 & 826 \\
NA & 0.5415 & 0.06 & 122.97 & -0.95 & 4.457 & 25.28182 & 691.0031 & 826 \\
\hline
\end{tabular}

Notes: Shareholder-R, Employee-R, Supply chain-R, Environmental-R, Public-R MB, and NA in Table 1 is short for Shareholder-Responsibility, Employee-Responsibility, Suppliers, customers and consumers responsibility, Environmental-Responsibility, Public-Responsibility, Growth Rate of Main Operating and Expansion Rate of Net Assets Respectively. 


\section{Measures of CSR and CFP}

\subsection{Financial Performance}

Raze et al. have summarised numerous empirical studies from 1972-2012 in their review paper using content analysis, showing that financial measures such as stock market returns, Tobin's Q, and accounting profits ratios such as return on assets (ROA), return on equity (ROE), and return on sales (ROS) are targeted [38]. Most scholars choose ROE, ROA, EPS, and ROIC as important financial variables in their studies [2,7,39-41]. Scholtens (2008) uses stock returns as a financial index [42]. McGuire et al. compare both stock market-based and accounting-based measures that focus on different aspects of financial performance. The accounting-based measures emphasise the firm's historical performance and capture a wide range of indicators such as ROA, ROE, Growth Rate of Main Operating, and Expansion Rate of Net Assets [41]. Stock market-based measures refer to investors' evaluations and expectations of firms. However, these measures may not reflect the real evaluation if there is asymmetric information [42]. In the Chinese mineral industry, firms would face all types of stakeholders, and it is not feasible for them to only focus on investors. Thus, this paper takes into account both stock-market returns and accounting-based measures. We employ EPS as a market-based CFP index and ROA, ROE, Growth Rate of Main Operating, and Expansion Rate of Net Assets as accounting-based CFP indicators.

\subsection{CSR Performance}

Over the decades, the concept of Corporate Social Responsibility (CSR) has continued to grow in importance and significance, although there is generally no consistent definition. Even competing, complementary, and overlapping concepts such as corporate citizenship, business ethics, stakeholder management, and sustainability are all vying to become the most accepted and widespread descriptor of the field [11]. As there is generally no consistent definition, there is also no consistent evaluation of CSR performance. Scholars use different methods to assess CSR performance. Some studies have used questionnaires answered by CEOs or managers for CSR performance [21]. McGuire used an enterprise's reputation released by FORTUNE magazine as CSR performance [41]. Some CSR performance is based on KLD's measures, which use multidimensional variables capturing a wide range of stakeholder performance aspects $[42,43]$. In recent years, studies also evaluated CSR performance based on the firms' CSR reports [44]. Furthermore, scholars even establish their own evaluation systems for specific industries such as the construction and infrastructure industry $[45,46]$.

As for China, the CSR field is just in the fledging period. Most Chinese firms' CSR reports were first released in 2010 when required by the State-owned Assets Supervision and Administration Commission of the State Council. In this study, we cited CSR performance evaluation data from a professional Chinese financial website named HEXUN, which evaluated CSR performance every year from 2010 on all listed Chinese firms. According to the website, CSR is divided into five sub-levels: shareholder responsibility, employee responsibility, supplier, customer and consumer rights responsibility, environmental responsibility, and social responsibility based on stakeholder theory. Each of the elements also has several sub-criteria. Shareholder responsibility includes profitability, debt situation, return, credit, and innovation. Employee responsibility covers performance, security, and 
caring for employees. Supplier, customer, and consumer responsibility mainly focuses on product quality, service, and mutual good faith. Environmental responsibility is composed of environmental awareness, environmental management system certification, environmental investment amount, number of sewage types, and number of energy conservation types. Public responsibility represents a firm's contribution value, which covers taxes and donations. The detailed definitions of each variable are provided in Appendix A.

\subsection{Firm's Sector}

In China, there is no clear definition of the minerals industry. Usually there is a wide range of industries which are related to mine exploitation and operation. Their businesses are closely tied with natural resources; most firms have extractive and downstream processing functions as well as a smelting sector. In this paper, the firms we chose are from the HEXUN website, which evaluates the CSR performance of all Chinese listed firms. In their open online CSR evaluation database, the firms are classified into 35 industries according to the Industry Classification Benchmark (ICB). We choose the industries which are closely related to natural resources, which are the extractive industry, metal fabrication industry, oil and gas industry, gas and water-related industry, and oil-producing equipment industry, comprising of 228 firms (see Appendix B, Table B2). These five sectors are basically different from each other by production. As their CSR performance is quite different from each other, we want to study the detailed relationship between CSR and CFP so that we can make feasible suggestions for solving these problems.

\section{Models}

This study is designed to examine the relationship between CSR and CFP. It appears that the regression model is used to investigate the association between social and financial performance [42]. Regression analysis is a statistical process for estimating the relationships among variables. This method has been developed considerably. Pooled regression can be used when the groups to be pooled are relatively similar or homogenous. Again, it is the regression model with Pooled Least Squares that is used to investigate the association between CSR and CFP in the Chinese mineral industry.

As our samples are extremely equal to all of the listed mineral companies in China and the data period is relatively short (because the CSR field in China has just started in recent years, CSR data are limited though we have found all of the available data), the firms-fixed effects regression model was adopted in this research and we passed over the unit root test for the short term data.

Equation (1) examines the relationship between unitary CSR and CFP. The two variables are CFP and CSR, which are calculated by the CFP ratio and total CSR score. Equation (2) provides a further study of the internal relationship among CSR elements and CFP. All of the CSR sub-criteria are explanatory variables in regression Equation (2) where S, EM, EN, P, C stands for shareholder responsibility, employee responsibility, environmental responsibility, public responsibility, and supplier, customer and consumer responsibility, respectively.

Following previous research studies, some other determinants that may have effects on financial performance also should be included in the estimation equation as supplementary explanatory variables in addition to CSR performance, such as input and tax credit. However, data collection was a 
significant problem because we could not obtain data for all 228 firms. As our research mainly focuses on the relationship between CSR and CFP, we would like to include the supplementary explanatory variables as part of the constant $\beta_{0}$. Our basic equations are expressed as follows:

$$
\begin{gathered}
C F P_{i t}=\beta_{0}+\beta_{1} C S R_{i t}+\mu_{j}+\varepsilon_{i t} \\
C F P_{i t}=\beta_{0}+\beta_{1} S_{i t}+\beta_{2} E M_{i t}+\beta_{3} C_{i t}+\beta_{4} E N_{i t}+\beta_{5} p_{i t}+\mu_{j}+\varepsilon_{i t}
\end{gathered}
$$

where $i$ represents the firm; $j$ refers to the industry; $t$ indicates the period; $\mu$ is the firm fixed effects, which will be introduced later; and $\varepsilon$ is the standard error term. The CFP performance indicators are ROE, ROA, Growth Rate of Main Operating, Expansion Rate of Net Assets, and EPS.

Our analysis moves as follows. First, we use the full sample data of 228 mineral firms to estimate Equations (1) and (2). Second, we examine the relationship between CSR and CFP in the five mineral sub-sectors.

We adopt software EVIEWS 6.0 to do estimation. After the estimation proceeds, it is important to improve the estimation quality. If the variable could not pass the t-test and the $\mathrm{P}$ value, then we reduce insignificant variables gradually. However, the analysis shows that reducing the variables still could not improve the equation's quality. The possible reason is that these variables do not have significant effects on the dependent variable (CFP).

\section{Results and Discussion}

\subsection{The Relationship between CSR and CFP across All 228 Firms}

The estimation results of the full sample (228 firms) are shown in Table 2. CSR has significant positive effects on ROA, and EPS in columns (2)-(3), judging from the value of $\mathrm{R}^{2}$ and the t-test. The results show that CSR may have positive connections with firm profits. CSR does not show significant effects on the growth rate of the main operating or expansion rate of net assets, which shows that CSR does not have a relationship with corporate main operating revenue. Based on the above, CSR issues may help the company reduce costs and then lead to a profit increase.

As for the CSR elements, shareholder responsibility performance has a significant positive effect on most CFP indicators (except for the growth rate of main operating). This finding implies that shareholder responsibility has impacts on firm cost reduction. Shareholder responsibility is composed of profits, debt situation, return, credit, and innovation (see Appendix A), which mainly focus on the issues inside the firm; Apart from shareholder responsibility, supplier, customer and consumer rights responsibility has negative effect on EPS, which means that product quality, service and mutual faith has negative effects on earning. The spare sub-criteria of CSR do not show a significant impact on a firm's financial performance. This finding indicates that the other stakeholders such as the employees, community, clients, and the public do not have significant positive effects on CFP. In addition, only the CSR issues closely related to company operations could have effects on CFP, which is why mineral companies do not have the necessity or motivation for CFP, leading to conflicts. 
Table 2. Estimation results for the relationship between CSR and CFP in all 228 firms.

\begin{tabular}{lccccc}
\hline & $\mathbf{( 1 )}$ & $\mathbf{( 2 )}$ & $\mathbf{( 3 )}$ & $\mathbf{( 4 )}$ & $\mathbf{( 5 )}$ \\
& $\mathbf{R O E}$ & $\mathbf{R O A}$ & $\mathbf{E P S}$ & $\mathbf{M B}$ & $\mathbf{N A}$ \\
\hline Constant & -0.0697 & $0.0240 * * *$ & $0.1419 * * *$ & 0.6688 & $1.0431 * * *$ \\
& $(-0.7599)$ & $(3.7270)$ & $(3.8104)$ & $(0.6554)$ & $(2.7456)$ \\
\hline CSR & 0.0045 & $0.0005 * * *$ & $0.0076 * * *$ & 0.0038 & -0.0177 \\
& $(-1.6336)$ & $(2.7476)$ & $(6.8297)$ & $(0.1241)$ & $(-1.5666)$ \\
\hline $\mathrm{R}^{2}$ & 0.2741 & 0.4851 & 0.5170 & 0.2476 & 0.2517 \\
\hline Constant & $-0.9952 * * *$ & $-0.1291 * * *$ & $-0.9048 * * *$ & -0.7452 & -0.6596 \\
& $(-5.1824)$ & $(-11.5355)$ & $(-15.7045)$ & $(-0.3474)$ & $(-0.8233)$ \\
\hline Shareholder responsibility & $0.0852 * * *$ & $0.0139 * * *$ & $0.1000 * * *$ & 0.1321 & $0.1217 * *$ \\
& $(6.0852)$ & $(16.8531)$ & $(23.5878)$ & $(0.8359)$ & $(2.0758)$ \\
\hline Employee Responsibility & -0.0083 & -0.0013 & 0.0023 & 0.1454 & -0.1614 \\
& $(-0.3012)$ & $(-0.7926)$ & $(0.2694)$ & $(0.4599)$ & $(1.3926)$ \\
\hline Suppliers, customers and consumers responsibility & 0.0033 & 0.0004 & $-0.0175 * *$ & -0.0609 & 0.0322 \\
& $(0.1432)$ & $(0.2615)$ & $(-2.4731)$ & $(-0.2310)$ & $(0.3338)$ \\
\hline Environmental Responsibility & -0.0032 & -0.0011 & 0.0086 & -0.0359 & -0.0199 \\
& $(-0.1935)$ & $(-1.1148)$ & $(1.7122)$ & $(-0.1915)$ & $(-0.2904)$ \\
\hline Public Responsibility & 0.0019 & 0.0004 & -0.0001 & -0.1072 & 0.0844 \\
& $(0.0958)$ & $(0.3766)$ & $(-0.0169)$ & $(-0.4767)$ & $(1.0257)$ \\
\hline $\mathrm{R}^{2}$ & 0.3147 & 0.6494 & 0.7393 & 0.2488 & 0.2648 \\
\hline No. of firms & 228 & 228 & 228 & 228 & 227 \\
\hline Observations & 838 & 842 & 842 & 840 & 830 \\
\hline
\end{tabular}

Notes: 1 . The numbers in parentheses are the t-test value; 2 . The asterisks $* * *, * *$, and $*$ indicate $1 \%, 5 \%$, and $10 \%$ significance levels, respectively; 3. "MB" is the abbreviation for growth rate of main operating and "NA" is the abbreviation for expansion rate of net assets.

A possible reason for the results is China's mineral industry development period. Different development periods led to different developing environments. Developed countries have robust legislation and monitoring regulations. Whereas, at present in developing countries such as China that lack legislative constraints and effective monitoring measures, companies find that there is very little financial consequence for ignoring CSR. They are typically in a self-regulation position. For example, there are numerous economic incentives from tax breaks and low royalty payments, which may worsen public conditions, destroy the environment, and cheat the government [47]. In this period, CSR issues that do not have close ties to CFP (usually the stakeholders' interests outside a firm's operations) would be abandoned by the corporations.

\subsection{The Relationship between CSR and CFP in the Extractive Industry}

The estimation results in the extractive industry are shown in Table 3. CSR has significant positive impacts on ROA, EPS and insignificant effects on the other three CFP indices. This result indicates that CSR has long-run effects on CFP because ROA includes both assets and equity. 
Table 3. Estimation results for the relationship between CSR and CFP in the extractive industry.

\begin{tabular}{|c|c|c|c|c|c|}
\hline & $\begin{array}{c}(1) \\
\text { ROE }\end{array}$ & $\begin{array}{c}(2) \\
\text { ROA }\end{array}$ & $\begin{array}{c}\text { (3) } \\
\text { EPS }\end{array}$ & $\begin{array}{l}(4) \\
\text { MB }\end{array}$ & $\begin{array}{l}(\mathbf{5}) \\
\text { NA }\end{array}$ \\
\hline Constant & $\begin{array}{c}0.0010 \\
(0.0366) \\
\end{array}$ & $\begin{array}{c}0.0437 * * * \\
(2.7756) \\
\end{array}$ & $\begin{array}{c}0.1984 * * \\
(2.2382) \\
\end{array}$ & $\begin{array}{c}0.0282 \\
(0.0534) \\
\end{array}$ & $\begin{array}{r}0.3014 \\
(1.0587) \\
\end{array}$ \\
\hline CSR & $\begin{array}{c}0.0028 * * * \\
(3.6027)\end{array}$ & $\begin{array}{c}0.0003 \\
(0.8598)\end{array}$ & $\begin{array}{c}0.0106 * * * \\
(4.2582)\end{array}$ & $\begin{array}{c}0.0149 \\
(1.0039)\end{array}$ & $\begin{array}{c}0.0012 \\
(0.1550)\end{array}$ \\
\hline $\mathrm{R}^{2}$ & 0.4868 & 0.4067 & 0.6511 & 0.2505 & 0.3108 \\
\hline Constant & $\begin{array}{c}-0.3570^{* * *} \\
(-7.6557)\end{array}$ & $\begin{array}{c}-0.1252 * * * \\
(-4.9331)\end{array}$ & $\begin{array}{c}-0.6663 \text { *** } \\
(-4.6403)\end{array}$ & $\begin{array}{c}-0.6227 \\
(-0.6052)\end{array}$ & $\begin{array}{c}-0.5822 \\
(-1.0267)\end{array}$ \\
\hline Shareholder responsibility & $\begin{array}{c}0.0319 * * * \\
(9.9717)\end{array}$ & $\begin{array}{c}0.0139 * * * \\
(7.7350)\end{array}$ & $\begin{array}{c}0.0912 * * * \\
(8.9584)\end{array}$ & $\begin{array}{c}0.1287^{*} \\
(1.7639) \\
\end{array}$ & $\begin{array}{c}0.0900 * * \\
(2.2854)\end{array}$ \\
\hline Employee Responsibility & $\begin{array}{c}0.0061 \\
(0.7988) \\
\end{array}$ & $\begin{array}{c}0.0013 \\
(0.2977) \\
\end{array}$ & $\begin{array}{c}-0.0138 \\
(-0.5468) \\
\end{array}$ & $\begin{array}{c}-0.1739 \\
(-0.9606) \\
\end{array}$ & $\begin{array}{c}-0.0608 \\
(-0.6352) \\
\end{array}$ \\
\hline Suppliers, customers and consumers responsibility & $\begin{array}{c}0.0032 \\
(0.4674)\end{array}$ & $\begin{array}{c}0.0040 \\
(0.9900)\end{array}$ & $\begin{array}{c}0.0251 \\
(1.1010)\end{array}$ & $\begin{array}{c}0.1076 \\
(0.6584) \\
\end{array}$ & $\begin{array}{c}0.0593 \\
(0.6928)\end{array}$ \\
\hline Environmental Responsibility & $\begin{array}{c}-0.0059 \\
(-1.6302)\end{array}$ & $\begin{array}{c}-0.0058 * * * \\
(-2.7387)\end{array}$ & $\begin{array}{c}-0.0043 \\
(-0.3550)\end{array}$ & $\begin{array}{c}0.0441 \\
(0.5097)\end{array}$ & $\begin{array}{c}-0.0171 \\
(-0.3730)\end{array}$ \\
\hline Public Responsibility & $\begin{array}{c}0.0019 \\
(0.3770) \\
\end{array}$ & $\begin{array}{c}0.0018 \\
(0.5839) \\
\end{array}$ & $\begin{array}{c}-0.0057 \\
(-0.3280) \\
\end{array}$ & $\begin{array}{c}-0.0945 \\
(-0.7628) \\
\end{array}$ & $\begin{array}{c}-0.0264 \\
(-0.4065)\end{array}$ \\
\hline $\mathrm{R}^{2}$ & 0.6875 & 0.6040 & 0.7646 & 0.2677 & 0.3391 \\
\hline No. of firms & 54 & 54 & 54 & 54 & 54 \\
\hline Observations & 204 & 205 & 205 & 205 & 200 \\
\hline
\end{tabular}

Notes: 1 . The numbers in parentheses are the t-test value; 2 . The asterisks $* * *, * *$, and $*$ indicate $1 \%, 5 \%$, and $10 \%$ significance levels, respectively; 3. "MB" is the abbreviation for growth rate of main operating and "NA" is the abbreviation for expansion rate of net assets.

As for the CSR elements, shareholder responsibility has significant positive impacts on all CFP indicators in Columns (1)-(5). Environmental performance also has a significant negative impact on ROA, which shows that it has negative effects on profits. The other elements of CSR do not have effects on CFP over the $90 \%$ significance level.

The difference in the estimation results between the extractive industry and all 228 firms is that environmental performance has negative effects on profits. One explanation for the difference is the extractive industry's characteristics. The extractive industry is highly polluting, which has aroused the attention of the government and public. As a result of the pressure of these stakeholders, extractive firms must take measures to respond to the environment, which increases costs, burdens the company, and reduces profits.

\subsection{The Relationship between CSR and CFP in the Metal Fabrication Industry}

The estimation results in the metal fabrication industry are shown in Table 4. CSR performance has significant positive effects on ROA and EPS. The results show that CSR has positive effects on corporate profits by reducing the cost. 
Table 4. Estimation results for the relationship between CSR and CFP in the metal fabrication industry.

\begin{tabular}{lccccc}
\hline & $\mathbf{( 1 )}$ & $\mathbf{( 2 )}$ & $\mathbf{( 3 )}$ & $\mathbf{( 4 )}$ & $\mathbf{( 5 )}$ \\
& $\mathbf{R O E}$ & $\mathbf{R O A}$ & $\mathbf{E P S}$ & $\mathbf{M B}$ & $\mathbf{N A}$ \\
\hline Constant & 0.0213 & -0.0037 & 0.0368 & 0.9029 & $1.4019^{*}$ \\
& $(0.1110)$ & $(-0.2748)$ & $(0.6213)$ & $(0.4354)$ & $(1.8457)$ \\
\hline CSR & 0.0004 & $0.0009 * *$ & $0.0067 * * *$ & 0.0097 & -0.0293 \\
& $(0.0756)$ & $(2.5287)$ & $(3.7062)$ & $(0.1530)$ & $(-1.2776)$ \\
\hline $\mathrm{R}^{2}$ & 0.2392 & 0.3507 & 0.3621 & 0.2491 & 0.2550 \\
\hline Constant & $-1.4258 * * *$ & $-0.1825 * * *$ & $-1.0406 * * *$ & -1.5605 & -1.5963 \\
& $(-4.2340)$ & $(-10.074)$ & $(-14.6465)$ & $(-0.4131)$ & $(-1.1750)$ \\
\hline Shareholder responsibility & $0.1499 * * *$ & $0.0186 * * *$ & $0.1129 * * *$ & 0.2281 & $0.2448 * *$ \\
& $(5.3569)$ & $(12.2328)$ & $(18.9117)$ & $(0.7179)$ & $(2.1436)$ \\
\hline Employee Responsibility & 0.0072 & 0.0047 & $0.0210 *$ & 0.4905 & 0.0713 \\
& $(0.1318)$ & $(1.5446)$ & $(1.7771)$ & $(0.7820)$ & $(0.3213)$ \\
\hline Suppliers, customers and consumers responsibility & 0.0304 & -0.0023 & $-0.0360 * * *$ & -0.1827 & -0.3267 \\
& $(0.5266)$ & $(-0.7185)$ & $(-2.8982)$ & $(-0.2767)$ & $(-1.3977)$ \\
\hline Environmental Responsibility & -0.0389 & -0.0021 & 0.0040 & -0.1140 & 0.0240 \\
& $(-1.1361)$ & $(-1.1073)$ & $(0.5435)$ & $(-0.2915)$ & $(0.1734)$ \\
\hline Public Responsibility & -0.0626 & -0.0028 & -0.0038 & -0.3026 & 0.0307 \\
& $(-1.5204)$ & $(-1.2402)$ & $(-0.4298)$ & $(-0.6400)$ & $(0.1813)$ \\
\hline $\mathrm{R}^{2}$ & 0.3121 & 0.5737 & 0.7241 & 0.2520 & 0.2795 \\
\hline No. of firms & 113 & 113 & 113 & 113 & 113 \\
\hline Observations & 407 & 410 & 410 & 408 & 403 \\
\hline
\end{tabular}

Notes: 1 . The numbers in parentheses are the t-test value; 2 . The asterisks $* * *, * *$, and * indicate $1 \%, 5 \%$, and $10 \%$ significance levels, respectively; 3. "MB" is the abbreviation for growth rate of main operating and "NA" is the abbreviation for expansion rate of net assets.

As for CSR elements, (1) shareholder responsibility has significant positive effects on most CFP indices (except for the growth rate of main operating); (2) supplier, customer, and consumer responsibility has negative effects on EPS; (3) employee responsibility has positive effects on the EPS; and (4) apart from the three CSR elements above, the other sub-criteria do not show a significant impact on a firm's financial performance. These results imply that in the metal fabrication industry, shareholder responsibility and employee responsibility has positive effects on profits. These results also show that the other stakeholders such as community and the public do not have a significant relationship with CFP.

Metal fabrication mainly uses materials that must be of good quality, which leads to cost increases and profit reductions. Quality management may have short-run negative effects and long-run positive effects on a firm's profits. Employee responsibility may increase employee motivation and lead to profit increase. Results show that only the CSR issues that are closely related to a company's traditional operations have effect on CFP. 


\subsection{The Relationship between CSR and CFP in the Oil and Gas Industry}

The estimation results in the oil and gas industry are shown in Table 5. CSR performance only has a significant positive effect on EPS over the $90 \%$ significance level.

Table 5. Estimation results for the relationship between CSR and CFP in the oil and gas industry.

\begin{tabular}{|c|c|c|c|c|c|}
\hline & $\begin{array}{c}(1) \\
\text { ROE }\end{array}$ & $\begin{array}{c}(2) \\
\text { ROA }\end{array}$ & $\begin{array}{c}\text { (3) } \\
\text { EPS }\end{array}$ & $\begin{array}{l}(4) \\
\text { MB }\end{array}$ & $\begin{array}{l}\text { (5) } \\
\text { NA }\end{array}$ \\
\hline Constant & $\begin{array}{c}0.0446 * * \\
(2.5029)\end{array}$ & $\begin{array}{c}0.0186 * * \\
(2.1852)\end{array}$ & $\begin{array}{c}0.1999 * * \\
(3.4810)\end{array}$ & $\begin{array}{c}0.0516 \\
(0.2182)\end{array}$ & $\begin{array}{c}0.2072 \\
(1.0169)\end{array}$ \\
\hline CSR & $\begin{array}{c}0.0010 \\
(1.5123)\end{array}$ & $\begin{array}{c}0.0003 \\
(1.2822)\end{array}$ & $\begin{array}{l}0.0039 * \\
(1.9008)\end{array}$ & $\begin{array}{c}0.0088 \\
(1.0587)\end{array}$ & $\begin{array}{c}0.0029 \\
(0.3972)\end{array}$ \\
\hline $\mathrm{R}^{2}$ & 0.6416 & 0.5843 & 0.79283 & 0.2445 & 0.5621 \\
\hline Constant & $\begin{array}{l}-0.0835 * \\
(-2.0579)\end{array}$ & $\begin{array}{c}-0.0427 * * \\
(-2.2468)\end{array}$ & $\begin{array}{c}-0.2754 * * \\
(-2.3719)\end{array}$ & $\begin{array}{c}-0.8615 \\
(-1.4376)\end{array}$ & $\begin{array}{c}-0.6665 \\
(-1.2098)\end{array}$ \\
\hline Shareholder responsibility & $\begin{array}{c}0.0099 * * \\
(2.8251)\end{array}$ & $\begin{array}{c}0.0046 * * * \\
(2.8349)\end{array}$ & $\begin{array}{c}0.0370 * * \\
(3.6746)\end{array}$ & $\begin{array}{c}0.0482 \\
(0.9275)\end{array}$ & $\begin{array}{l}0.0829 * \\
(1.7371)\end{array}$ \\
\hline Employee Responsibility & $\begin{array}{r}0.0083 \\
(0.9485) \\
\end{array}$ & $\begin{array}{c}0.0049 \\
(1.1927) \\
\end{array}$ & $\begin{array}{c}0.0326 \\
(1.3045) \\
\end{array}$ & $\begin{array}{l}0.2569 * \\
(1.9898)\end{array}$ & $\begin{array}{c}-0.0354 \\
(-0.2986)\end{array}$ \\
\hline Suppliers, customers and consumers responsibility & $\begin{array}{c}-0.0005 \\
(-0.0557)\end{array}$ & $\begin{array}{c}0.0003 \\
(0.0764) \\
\end{array}$ & $\begin{array}{c}-0.0004 \\
(-0.0135)\end{array}$ & $\begin{array}{c}-0.1391 \\
(-0.9913)\end{array}$ & $\begin{array}{c}0.0323 \\
(0.2506) \\
\end{array}$ \\
\hline Environmental Responsibility & $\begin{array}{c}-0.0036 \\
(-0.8726)\end{array}$ & $\begin{array}{c}-0.0025 \\
(-1.3132)\end{array}$ & $\begin{array}{c}-0.0143 \\
(-1.2250)\end{array}$ & $\begin{array}{c}-0.0381 \\
(-0.6317)\end{array}$ & $\begin{array}{c}-0.0032 \\
(-0.0579)\end{array}$ \\
\hline Public Responsibility & $\begin{array}{c}0.0043 \\
(1.3331)\end{array}$ & $\begin{array}{c}0.0016 \\
(1.0253)\end{array}$ & $\begin{array}{l}0.0163 * \\
(1.7571)\end{array}$ & $\begin{array}{c}0.0265 \\
(-0.5541)\end{array}$ & $\begin{array}{c}0.0014 \\
(-0.0310)\end{array}$ \\
\hline $\mathrm{R}^{2}$ & 0.7782 & 0.7517 & 0.9256 & 0.4209 & 0.618 \\
\hline No. of firms & 9 & 9 & 9 & 9 & 9 \\
\hline Observations & 35 & 35 & 35 & 35 & 35 \\
\hline
\end{tabular}

Notes: 1 . The numbers in parentheses are the t-test value; 2 . The asterisks $* * *, * *$, and $*$ indicate $1 \%, 5 \%$, and $10 \%$ significance levels, respectively; 3. "MB" is the abbreviation for growth rate of main operating and "NA" is the abbreviation for expansion rate of net assets.

As for the CSR elements, (1) shareholder responsibility has a significant positive effect on most CFP indices (except for the growth rate of main operating); (2) employee responsibility has a significant positive impact on growth rate of main operating; (3) public responsibility has a positive effect on EPS, indicating that tax and charity has positive effects on profits; and (4) the other elements have no significant relationship with CFP.

The difference from other industries regarding the relationship between CSR and CFP is that public responsibility has significant positive impacts on EPS. One possible explanation for the result is that most oil and gas companies are state-owned, obtaining huge profits and attracting a large amount of public attention. Public responsibility may improve consumer loyalty and coordination with the local community in the exploitation process. Caring for employees would encourage the staff to work better, and their good performance would improve financial performance. 


\subsection{The Relationship between CSR and CFP in the Oil-Producing Equipment Industry}

The estimation results in the oil-producing equipment industry are shown in Table 6. CSR has negative effects on the growth rate of main operating. Shareholder responsibility performance has positive effects on ROE, ROA, and EPS over the 90\% significance level. CSR does not show a significant effect on the growth rate of main operating or expansion rate of net assets, which shows that CSR does not have a relationship with corporate main operating revenue. Based on the above, CSR issues may help the company reduce costs, leading to a profit increase.

Table 6. Estimation results for the relationship between CSR and CFP in the oil-producing equipment industry.

\begin{tabular}{|c|c|c|c|c|c|}
\hline & $\begin{array}{c}(1) \\
\text { ROE }\end{array}$ & $\begin{array}{c}(2) \\
\text { ROA }\end{array}$ & $\begin{array}{c}(3) \\
\text { EPS }\end{array}$ & $\begin{array}{l}(4) \\
\text { MB } \\
\end{array}$ & $\begin{array}{r}(5) \\
\text { NA } \\
\end{array}$ \\
\hline Constant & $\begin{array}{c}0.1142 * * * \\
(4.1215)\end{array}$ & $\begin{array}{c}0.0819 * * * \\
(4.1082)\end{array}$ & $\begin{array}{c}0.7682 * * * \\
(6.8067)\end{array}$ & $\begin{array}{c}0.4095 * * * \\
(4.1124)\end{array}$ & $\begin{array}{l}1.1438 * \\
(1.8906)\end{array}$ \\
\hline CSR & $\begin{array}{l}-0.0002 \\
(-0.1942)\end{array}$ & $\begin{array}{l}-0.0003 \\
(-0.5319)\end{array}$ & $\begin{array}{l}-0.0053 \\
(-1.4573)\end{array}$ & $\begin{array}{l}-0.0056 * \\
(-1.7474)\end{array}$ & $\begin{array}{c}-0.0108 \\
(-0.5507)\end{array}$ \\
\hline $\mathrm{R}^{2}$ & 0.5002 & 0.5610 & 0.7630 & 0.3468 & 0.1920 \\
\hline Constant & $\begin{array}{c}-0.0990 \\
(-1.0520)\end{array}$ & $\begin{array}{c}-0.0471 \\
(-0.6803)\end{array}$ & $\begin{array}{c}-0.1993 \\
(-0.5251)\end{array}$ & $\begin{array}{c}0.0568 \\
(0.1686)\end{array}$ & $\begin{array}{c}0.9689 \\
(0.4144)\end{array}$ \\
\hline Shareholder responsibility & $\begin{array}{c}0.0147 * * * \\
(2.8654)\end{array}$ & $\begin{array}{c}0.0091 * * \\
(2.4190) \\
\end{array}$ & $\begin{array}{c}0.0588 * * * \\
(2.8408) \\
\end{array}$ & $\begin{array}{r}0.0290 \\
(1.5762) \\
\end{array}$ & $\begin{array}{r}0.0183 \\
(0.1434) \\
\end{array}$ \\
\hline Employee Responsibility & $\begin{array}{c}-0.0066 \\
(-0.8019) \\
\end{array}$ & $\begin{array}{c}-0.0045 \\
(-0.7463) \\
\end{array}$ & $\begin{array}{l}-0.0169 \\
(-0.5095)\end{array}$ & $\begin{array}{c}-0.0315 \\
(-1.0699)\end{array}$ & $\begin{array}{r}0.0756 \\
(0.3698) \\
\end{array}$ \\
\hline Suppliers, customers and consumers responsibility & $\begin{array}{c}0.0020 \\
(0.2431) \\
\end{array}$ & $\begin{array}{c}0.0010 \\
(0.1544) \\
\end{array}$ & $\begin{array}{c}-0.0109 \\
(-0.3256)\end{array}$ & $\begin{array}{c}-0.0395 \\
(-1.3320)\end{array}$ & $\begin{array}{c}-0.0420 \\
(-0.2040)\end{array}$ \\
\hline Environmental Responsibility & $\begin{array}{c}0.0017 \\
(0.2892) \\
\end{array}$ & $\begin{array}{c}0.0014 \\
(0.3065) \\
\end{array}$ & $\begin{array}{c}0.0032 \\
(0.1331) \\
\end{array}$ & $\begin{array}{c}0.0329 \\
(1.5288) \\
\end{array}$ & $\begin{array}{c}-0.0061 \\
(-0.0412)\end{array}$ \\
\hline Public Responsibility & $\begin{array}{c}-0.0016 \\
(-0.1534)\end{array}$ & $\begin{array}{c}-0.0037 \\
(-0.4761) \\
\end{array}$ & $\begin{array}{c}-0.0080 \\
(-0.1888)\end{array}$ & $\begin{array}{c}-0.0548 \\
(-1.4658)\end{array}$ & $\begin{array}{l}-0.1862 \\
(-0.7179)\end{array}$ \\
\hline $\mathrm{R}^{2}$ & 0.6242 & 0.6550 & 0.8259 & 0.5127 & 0.2144 \\
\hline No. of firms & 13 & 13 & 13 & 13 & 13 \\
\hline Observations & 49 & 49 & 49 & 49 & 49 \\
\hline
\end{tabular}

Notes: 1 . The numbers in parentheses are the t-test value; 2 . The asterisks $* * *, * *$, and * indicate $1 \%, 5 \%$, and $10 \%$ significance levels, respectively; 3. "MB" is the abbreviation for growth rate of main operating and "NA" is the abbreviation for expansion rate of net assets.

\subsection{The Relationship between CSR and CFP in the Gas and Water-Related Industry}

The estimation results for the gas and water-related industry are shown in Table 7. CSR has a positive relationship with ROE, ROA, and EPS. This situation is similar to all 228 firms, which shows that CSR may help reduce costs and lead to profit growth. 
Table 7. Estimation results for the relationship between CSR and CFP in the gas and water-related industry.

\begin{tabular}{|c|c|c|c|c|c|}
\hline & (1) & (2) & (3) & (4) & (5) \\
\hline & ROE & ROA & EPS & MB & NA \\
\hline Constant & $\begin{array}{c}0.0812 * * * \\
(4.2893) \\
\end{array}$ & $\begin{array}{c}0.0396 * * * \\
(4.6487) \\
\end{array}$ & $\begin{array}{c}0.3449 * * * \\
(4.6159) \\
\end{array}$ & $\begin{array}{c}0.1706 \\
(0.6704) \\
\end{array}$ & $\begin{array}{c}0.8041 \\
(1.5096) \\
\end{array}$ \\
\hline CSR & $\begin{array}{c}0.0006 \\
(0.9852) \\
\end{array}$ & $\begin{array}{c}0.0004 \\
(1.6025) \\
\end{array}$ & $\begin{array}{c}0.0034 \\
(1.4208) \\
\end{array}$ & $\begin{array}{c}0.0047 \\
(0.5746) \\
\end{array}$ & $\begin{array}{c}-0.0065 \\
(-0.3810) \\
\end{array}$ \\
\hline $\mathrm{R}^{2}$ & 0.4085 & 0.5794 & 0.6891 & 0.2154 & 0.2091 \\
\hline Constant & $\begin{array}{c}-0.1188 * * * \\
(-3.0962)\end{array}$ & $\begin{array}{c}-0.0650 * * * \\
(-4.0864)\end{array}$ & $\begin{array}{c}-0.5014 * * * \\
(-3.3772) \\
\end{array}$ & $\begin{array}{c}-0.9891 \\
(-1.6414)\end{array}$ & $\begin{array}{c}-0.3855 \\
(-0.2993) \\
\end{array}$ \\
\hline Shareholder responsibility & $\begin{array}{c}0.0165 * * * \\
(6.5508)\end{array}$ & $\begin{array}{c}0.0089 * * * \\
(8.4814)\end{array}$ & $\begin{array}{c}0.0697 * * * \\
(7.1515)\end{array}$ & $\begin{array}{l}0.0718 * \\
(1.8138)\end{array}$ & $\begin{array}{c}0.0643 \\
(0.7607) \\
\end{array}$ \\
\hline Employee Responsibility & $\begin{array}{l}-0.0171 * \\
(-1.9517)\end{array}$ & $\begin{array}{c}-0.0078 * * \\
(-2.1521)\end{array}$ & $\begin{array}{c}-0.0507 \\
(-1.4944)\end{array}$ & $\begin{array}{c}0.0087 \\
(0.0633) \\
\end{array}$ & $\begin{array}{c}-0.0655 \\
(-0.2226)\end{array}$ \\
\hline Suppliers, customers and consumers responsibility & $\begin{array}{c}0.0032 \\
(0.8919) \\
\end{array}$ & $\begin{array}{c}0.0010 \\
(0.6499) \\
\end{array}$ & $\begin{array}{c}-0.0009 \\
(-0.0640)\end{array}$ & $\begin{array}{c}0.0007 \\
(0.0116) \\
\end{array}$ & $\begin{array}{c}-0.0006 \\
(-0.0047) \\
\end{array}$ \\
\hline Environmental Responsibility & $\begin{array}{c}0.0016 \\
(0.4290) \\
\end{array}$ & $\begin{array}{c}0.0018 \\
(1.1245) \\
\end{array}$ & $\begin{array}{c}0.0192 \\
(1.3165) \\
\end{array}$ & $\begin{array}{c}-0.0236 \\
(-0.3985)\end{array}$ & $\begin{array}{c}-0.0226 \\
(-0.1785) \\
\end{array}$ \\
\hline Public Responsibility & $\begin{array}{c}0.0018 \\
(0.9736) \\
\end{array}$ & $\begin{array}{c}0.0005 \\
(0.6425) \\
\end{array}$ & $\begin{array}{c}0.0047 \\
(0.6734)\end{array}$ & $\begin{array}{c}0.0446 \\
(1.5603) \\
\end{array}$ & $\begin{array}{c}0.0477 \\
(0.7803) \\
\end{array}$ \\
\hline $\mathrm{R}^{2}$ & 0.5920 & 0.7532 & 0.7940 & 0.2610 & 0.2236 \\
\hline No. of firms & 39 & 39 & 39 & 39 & 39 \\
\hline Observations & 144 & 144 & 144 & 144 & 144 \\
\hline
\end{tabular}

Notes: 1 . The numbers in parentheses are the t-test value; 2 . The asterisks $* * *, * *$, and $*$ indicate $1 \%, 5 \%$, and $10 \%$ significance levels, respectively; 3. "MB" is the abbreviation for growth rate of main operating and "NA" is the abbreviation for expansion rate of net assets.

As for the CSR elements, (1) shareholder responsibility performance has positive effects on ROE, ROA, EPS and growth rate of main operating over the $90 \%$ significance level; (2) employee responsibility has negative effects on $\mathrm{ROE}$ and ROA, which implies that it may have a negative impact on profit but have long-run positive effects on profits because ROA includes both debt and equity capital.

\section{Conclusions}

To solve mineral conflicts and, even further, to maintain the sustainable development of the Chinese mineral industry as well as social harmony, mineral firms must adopt CSR ideas. This paper examines the relationship between CSR and financial performance using data from 228 Chinese mineral listed firms from 2010-2013 with Pooled Least Squares regression analysis.

The main findings in this paper are as follows: (1) overall, CSR has significant effects on ROA, ROE, and EPS, which indicates that CSR issues may help a company reduce costs, thereby leading to a profit increase; (2) shareholder responsibility is mainly positive in relation to a firm's profits. Environmental responsibility is mainly negative for profits in a highly polluting industry. The reason for these results is that a significantly polluting industry must spend a lot of money to decrease environmental impacts under the pressure of public attention. Employee responsibility has positive 
effects on firm profits in the metal fabrication industry and oil and gas industry, whereas it has short-run negative effects on profit in the water and gas-related industry. Public responsibility has positive effects on EPS in the oil and gas industry mainly because it can improve coordination with the local community in the exploitation process; (3) Generally, the CSR sub-criteria that have significant effects on a company's CFP are the stakeholders who are closely related to its business operations. Public responsibility does not show a significant relationship with CFP (except for the oil and gas industry), which may explain why so many mineral firms ignore the public interest, leading to fierce conflicts; (4) Different estimation results for the relationship between the CSR elements and CFP are due to industry characteristics.

The main reason for this phenomenon is the differing industry development periods and developing environments. In China, as the laws are imperfect and there are high costs associated with supervising companies, Chinese mineral firms have only economic incentives and not social responsibility incentives. Most mineral companies only pay attention to profits and have no interest in other public issues.

Our results have some policy implications for the relationship between firms and the government. Chinese mineral firms do not have much interest in stakeholder responsibility outside the firm, such as charities and taxes, because these issues are not closely related to CFP. This situation will improve if firms' profits are closely tied to their CSR performance within the mineral industry development environment. For example, if CSR faces a set of robust command-and-control regulations, then companies would incorporate CSR into their business models to operate normally and obtain profits. What is more, stimulating and restricting mechanisms must be combined. Besides enhancing supervision and legislation, we could implement some measures which would help to stimulate corporate initiatives; for example, provide tax reductions and exemptions to the firms which demonstrate excellent CSR performance, or enhance public awareness and education to improve the firm's devotion to CSR. Then, conflicts would gradually lessen, supporting the sustainable development of the Chinese mineral industry as well as social harmony.

These results can be regarded as a preliminary discussion about the relationship between CSR performance and CFP in the Chinese mineral industry. However, there is a caveat to our sample. As CSR is a relatively new concept for Chinese firms, data related to CSR is extremely limited. The time horizon of our sample data is relatively short, although we employed all available data to initiate this study. During our research period, the most recent data available is only from 2010-2013. Longer term data may provide a more promising research study.

\section{Acknowledgments}

The authors wish to thank Yan Jingjing, Zhang Hua, Ren Jingbo, and Xiang Nan, Zhang Dingding for their critical comments and suggestions. Furthermore, this research is funded by a project of the Key Laboratory of Carrying Capacity Assessment for Resource and Environment of the Ministry of Land and Resource (Grant No. CCA2012.11), and we wish to acknowledge their decision to submit the article for publication. The authors would also like to thank the editor of Sustainability and the two anonymous referees for their precious time and constructive comments on the paper. 


\section{Author Contributions}

Jinghua Sha jointly conceived the study with Xiping Pan, designed and implemented the regression model, prepared the manuscript, discussed the results and commented on the manuscript at all stages; Xiping Pan created the analytic model with contributions from Hongliang Zhang and Wenlan Ke, supervised its analysis and described the analytic model. Xiping Pan collected and interpreted the data, wrote and editing the paper.

\section{Appendix A}

(1) CSR Professional Evaluation System for Listed Companies Provided by the HEXUN Website

The CSR professional evaluation system uses the five aspects of shareholder responsibility, staff responsibility, suppliers, customers, and consumers responsibility, environmental responsibility, and public responsibility, which involves 13 secondary-class indicators and 37 third-class indicators.

Each different industry can have its own weight ratio distribution, but the typical distribution is the following: the shareholder responsibility weight accounted for $30 \%$ employee responsibility weight was $15 \%$; the supplier, customer, and consumer responsibility weight was $15 \%$; the environmental responsibility weight accounted for $20 \%$; and the social responsibility weight represented $20 \%$. In the consumer sector industry, the employee responsibility weight was $10 \%$; the supplier, customer, and consumer responsibility weight accounted for $20 \%$; and the other indicators' weight ratios remain unchanged. In the manufacturing industry, the environmental responsibility weight accounted for $30 \%$; the public responsibility weight accounted for $10 \%$; and the other index weight ratios remain unchanged. In the services industry, environmental responsibility accounted for $10 \%$ weight; the weight of social responsibility accounted for 30\%; and the other indicators' weights remain unchanged.

(2) Data Sources of Corporate Social Responsibility Professional Evaluation

(a) Corporate Social Responsibility report and annual report released by the official website listed in the Shanghai Stock Exchange.

(b) Corporate Social Responsibility report and annual report released by the official website listed in the Shenzhen Stock Exchange.

(3) Scoring Methods of Corporate Social Responsibility Professional Evaluation

(a) The social responsibility report professional evaluation index table describes in detail each index assignment.

(b) The indicators are divided into two categories: the first one is a numeric index, and the second one is a class of logic-based index. The numeric index is calculated using the data and hearing an accurate score based on the centre model; the logic-based index is based on the social responsibility report, as to whether there was disclosure of the indicators and the detailed disclosure score. 
(c) Due to different situations, the focus on shareholders; employees; supplier, customer, and consumer responsibility; the environment; and public responsibility is different, so there will be a corresponding adjustment in the assigned weights to be more reasonable.

Table A1. Data definitions and evaluation system.

\begin{tabular}{|c|c|c|}
\hline First-class indicators & Second-class indicators & Third-class indicators \\
\hline \multirow{18}{*}{$\begin{array}{l}\text { Shareholder responsibility }(\mathrm{A}) \\
\text { weight ratio: } 30 \%\end{array}$} & \multirow{6}{*}{ Profits (Aa) $10 \%$} & ROE $(2 \%)$ \\
\hline & & ROA $(2 \%)$ \\
\hline & & OPE $(2 \%)$ \\
\hline & & Cost margin $(1 \%)$ \\
\hline & & Earnings per share (EPS) $(2 \%)$ \\
\hline & & Retained earnings per share $(1 \%)$ \\
\hline & \multirow{5}{*}{ Debt situation $(\mathrm{Ab}) 3 \%$} & Quick ratio $(0.5 \%)$ \\
\hline & & Liquidity ratio $(0.5 \%)$ \\
\hline & & Cash ratio $(0.5 \%)$ \\
\hline & & Shareholders' equity ratio $(0.5 \%)$ \\
\hline & & Asset-liability ratio $(1 \%)$ \\
\hline & \multirow{3}{*}{ Return (Ac) 8\% } & Dividend capital ratio $(2 \%)$ \\
\hline & & Dividend yield (3\%) \\
\hline & & Bonus share allocation ratio of profits $(3 \%)$ \\
\hline & Credit (Ad) $5 \%$ & $\begin{array}{l}\text { Exchange of the company and the number of } \\
\text { responsible person penalties }(5 \%)\end{array}$ \\
\hline & & Product development expenditure (1\%) \\
\hline & Innovation (Ae) $4 \%$ & Concept of technological innovation (1\%) \\
\hline & & The number of items of technological innovation $(2 \%)$ \\
\hline \multirow{7}{*}{$\begin{array}{l}\text { Employee responsibilities (B) } \\
\text { weight ratio: } 15 \% \\
\text { weight: } 10 \% \text { in the consumer } \\
\text { sector }\end{array}$} & \multirow{2}{*}{ Performance (Ba) 5\% } & Per capita income of workers $(4 \%)(3 \%)$ \\
\hline & & Staff training $(1 \%)(1 \%)$ \\
\hline & \multirow{2}{*}{ Security $(\mathrm{Bb}) 5 \%$} & Security check $(2 \%)(1 \%)$ \\
\hline & & Safety training $(3 \%)(2 \%)$ \\
\hline & \multirow{3}{*}{ Caring for employees (Bc) 5\% } & Condolences awareness (1\%) (1\%) \\
\hline & & Condolences to the people $(2 \%)(1 \%)$ \\
\hline & & Condolence payments $(2 \%)(1 \%)$ \\
\hline \multirow{5}{*}{$\begin{array}{l}\text { Supplier, customer, and } \\
\text { consumers responsibility (C) } \\
\text { weight ratio: } 15 \% \\
\text { weight: } 20 \% \text { in the consumer } \\
\text { sector }\end{array}$} & \multirow{2}{*}{ Product quality $(\mathrm{Ca}) 7 \%$} & Quality management awareness (3\%) $(5 \%)$ \\
\hline & & Quality Management System Certificate (4\%) (4\%) \\
\hline & Service $(\mathrm{Cb}) 3 \%$ & Customer satisfaction survey $(3 \%)(4 \%)$ \\
\hline & \multirow{2}{*}{ Mutual good faith (Cc) 5\% } & Vendor fair competition $(3 \%)(4 \%)$ \\
\hline & & Anti-bribery training $(2 \%)(3 \%)$ \\
\hline
\end{tabular}

Environmental responsibility

(D) weight ratio: $20 \%$ weight: $30 \%$ in the manufacturing sector weight: $10 \%$ in the service sector
Environmental awareness

$(2 \%)(4 \%)(2 \%)$

Environmental management system certification

Environmental governance $\quad(3 \%)(5 \%)(2 \%)$

(Dd) $20 \%$

Environmental investment amount

$(5 \%)(7 \%)(2 \%)$

Number of types of sewage (5\%) (7\%) (2\%)

Number of types of energy conservation (5\%) (7\%) (2\%) 
Table A1. Cont.

\begin{tabular}{lll}
\hline First-class indicators & Second-class indicators & Third-class indicators \\
\hline $\begin{array}{l}\text { Public responsibility }(\mathrm{E}) \\
\text { weight ratio: } 20 \%\end{array}$ & & $\operatorname{Tax}(10 \%)(5 \%)(15 \%)$ \\
\cline { 2 - 2 } $\begin{array}{l}\text { weight: } 10 \% \text { in the } \\
\text { manufacturing sector }\end{array}$ & Contribution value (Ee) $20 \%$ & Donation amount (10\%) $(5 \%)(15 \%)$ \\
weight: $30 \%$ in the service & & \\
secto & & \\
\hline
\end{tabular}

\section{Appendix B}

Table B1. CFP Data Definitions and Sources.

\begin{tabular}{lll}
\hline \multicolumn{1}{c}{ Variable } & \multicolumn{1}{c}{ Description } \\
\hline ROE & Return on equity is defined as income for the term divided by total stockholders' equity \\
\hline ROA & $\begin{array}{l}\text { Return on assets is defined by the following ratio. The numerator is the sum of operating } \\
\text { profit, interest revenue/discount fee/interest on securities, and dividend revenue. The } \\
\text { denominator is the sum of liabilities and net assets. }\end{array}$ \\
\hline EPS & Earnings per share are defined as income for the term divided by total stockholders' equity. \\
\hline $\begin{array}{l}\text { Growth Rate of } \\
\text { Main Operating }\end{array}$ & The growth rate of the Revenue of the Main Business. \\
\hline $\begin{array}{l}\text { Expansion Rate of } \\
\text { Net Assets }(\%)\end{array}$ & The growth rate of Net Assets. \\
\hline
\end{tabular}

Table B2. Mining firms and classification.

\begin{tabular}{lll}
\hline Sectors & \multicolumn{1}{c}{ Company name } & Stock code \\
\hline & Chenzhou Mining Group Co., Ltd. & 002155 \\
& Sdic Xinji Energy Co., Ltd. & 601918 \\
& Shanxi Lanhua Sci -Tech Venture Co., Ltd. & 600123 \\
& Jizhong Energy Resources Co., Ltd. & 000937 \\
& Yunnan Chihong Zinc \& Germanium Co., Ltd. & 600497 \\
& Shanxi Lu'an Environmental Energy Development Co., Ltd. & 601699 \\
& Inner Mongolia Pingzhuang Energy Resources Co., Ltd. & 000780 \\
Extractive & China Shenhua Energy Company Limited. & 601088 \\
& Huolinhe Opencut Coal Industry Corporation Limited Of Inner Mongolia. & 002128 \\
& Shanxi Xishan Coal And Electricity Power Co., Ltd. & 000983 \\
& Zijin Mining Group Company Limited. & 601899 \\
& Yunnan Coal And Energy Co., Ltd. & 600792 \\
& Kailuan Energy Chemical Co., Ltd. & 600997 \\
& Shanxi Coal International Energy Group Co., Ltd. & 600546 \\
\hline
\end{tabular}


Table B2. Cont.

\begin{tabular}{|c|c|c|}
\hline Sectors & Company name & Stock code \\
\hline \multirow{40}{*}{ Extractive } & China Coal Energy Company Limited & 601898 \\
\hline & Shandong Jinling Mining Co., Ltd. & 000655 \\
\hline & Shanghai Prosolar Resources Development Co., Ltd. & 600193 \\
\hline & Yanzhou Coal Mining Company Limited & 600188 \\
\hline & Beijing Haohua Energy Resource Co., Ltd. & 601101 \\
\hline & China Molybdenum Co. Ltd. & 603993 \\
\hline & Shanghai Datun Energy Resources Co., Ltd. & 600508 \\
\hline & Tibet Mineral Development Co., Ltd. & 000762 \\
\hline & Taiyuan Coal Gasification Company Limited & 000968 \\
\hline & Shandong Dacheng Pesticide Co., Ltd. & 600882 \\
\hline & Gansu Jingyuan Coal Industry And Electricity Power Co., Ltd. & 000552 \\
\hline & Yang Quan Coal Industry (Group) Co., Ltd. & 600348 \\
\hline & Chifeng Jilong Gold Mining Co., Ltd. & 600988 \\
\hline & Henan Dayou Energy Co., Ltd. & 600403 \\
\hline & Shandong Gold Mining Co., Ltd. & 600547 \\
\hline & Guizhou Panjiang Refined Coal Co., Ltd. & 600395 \\
\hline & Anhui Hengyuan Coal Industry And Electricity Power Co., Ltd. & 600971 \\
\hline & Zhongjin Gold Corp., Ltd. & 600489 \\
\hline & Shandong Hongda Mining Co., Ltd. & 600532 \\
\hline & Sundiro Holding Co., Ltd. & 000571 \\
\hline & Zhengzhou Coal Industry \& Electric Power Co., Ltd. & 600121 \\
\hline & Xinjiang International Industry Co., Ltd. & 000159 \\
\hline & Anyuan Coal Industry Group Co., Ltd. & 600397 \\
\hline & Pingdingshan Tianan Coal Mining Co., Ltd. & 601666 \\
\hline & Sino-Platinum Metals Co., Ltd. & 600459 \\
\hline & Shanghai Ace Co., Ltd. & 600652 \\
\hline & Shandong Humon Smelting Co., Ltd. & 002237 \\
\hline & Datong Coal Industry Co., Ltd. & 601001 \\
\hline & Qinghai Jinrui Mineral Development Co., Ltd. & 600714 \\
\hline & Shanxi Antai Group Co., Ltd. & 600408 \\
\hline & Gansu Ronghua Industry Group Co., Ltd. & 600311 \\
\hline & Qitaihe Baotailong Coal\&Coal Chemicals Public Co., Ltd. & 601011 \\
\hline & Changchun Gas Co., Ltd. & 600333 \\
\hline & Shanxi Meijin Energy Co., Ltd. & 000723 \\
\hline & Shanxi Coking Co., Ltd. & 600740 \\
\hline & Heilongjiang Heihua Co., Ltd. & 600179 \\
\hline & Qinghai Sunshiny Mining Co., Ltd & 600381 \\
\hline & Jingu Yuan Holding., Ltd. & 000408 \\
\hline & Sichuan Shengda Industrial Co., Ltd. & 000835 \\
\hline & Shaanxi Coal And Chemical Industry Group Co., Ltd. & 601225 \\
\hline
\end{tabular}


Table B2. Cont.

\begin{tabular}{|c|c|c|}
\hline Sectors & Company name & Stock code \\
\hline \multirow{43}{*}{$\begin{array}{l}\text { Metal } \\
\text { Fabrication }\end{array}$} & Baoshan Iron \& Steel Co., Ltd. & 600019 \\
\hline & Yunnan Aluminium Co., Ltd. & 000807 \\
\hline & Nanjing Iron \& Steel Co., Ltd. & 600282 \\
\hline & Shenzhen Zhongjin Lingnan Nonfemet Co., Ltd. & 000060 \\
\hline & Henan Shen Huo Coal Industry And Electricity Power Co., Ltd. & 000933 \\
\hline & Yunnan Tin Co., Ltd. & 000960 \\
\hline & Guizhou Wire Rope Co., Ltd. & 600992 \\
\hline & Wuhan Iron And Steel Company Limited & 600005 \\
\hline & Shenzhen Green Eco-Manufacture Hi-Tech Co., Ltd. & 002340 \\
\hline & Fujian Minfa Aluminium Co., Ltd. & 002578 \\
\hline & Inner Mongolia Baotou Steel Rare-Earth (Group) Hi-Tech Co., Ltd. & 600111 \\
\hline & Xinxing Ductile Iron Pipes Co., Ltd. & 000778 \\
\hline & Pangang Group Vanadium Titanium \& Resources Co., Ltd. & 000629 \\
\hline & Jiaozuo Wanfang Aluminum Manufacturing Co., Ltd. & 000612 \\
\hline & China Nonferrous Metal Industry's Foreign Engineering And Construction Co., Ltd. & 000758 \\
\hline & Tongling Nonferrous Metals Group Co., Ltd. & 000630 \\
\hline & Beijing Cisri-gaona Materials \& Technology Co., Ltd. & 300034 \\
\hline & Shanxi Taigang Stainless Steel Co., Ltd. & 000825 \\
\hline & Chengtun Mining Group Co., Ltd. & 600711 \\
\hline & Gansu Jiu Steel Group Hongxing Iron \& Steel Co., Ltd. & 600307 \\
\hline & Xining Special Steel Co., Ltd. & 600117 \\
\hline & Baoji Titanium Industry Co., Ltd. & 600456 \\
\hline & Jiangxi Copper Company Limited. & 600362 \\
\hline & Henan Yuguang Gold And Lead Co., Ltd. & 600531 \\
\hline & Advanced Technology \& Materials Co., Ltd. & 000969 \\
\hline & Sansteel Minguang Co., Ltd., Fujian. & 002110 \\
\hline & Liuzhou Iron And Steel Co., Ltd. & 601003 \\
\hline & Western Mining Co., Ltd & 601168 \\
\hline & Hebei Iron And Steel Co., Ltd. & 000709 \\
\hline & Xiamen Tungsten Co., Ltd. & 600549 \\
\hline & Zhejiang Hailiang Co., Ltd. & 002203 \\
\hline & Henan Zhongfu Industrial Co., Ltd. & 600595 \\
\hline & Ningxia Orient Tantalum Industry Co., Ltd. & 000962 \\
\hline & Aluminum Corporation Of China Limited. & 601600 \\
\hline & Angang Steel Company Limited & 000898 \\
\hline & Jinduicheng Molybdenum Co., Ltd. & 601958 \\
\hline & Anhui Xinke New Materials Co., Ltd. & 600255 \\
\hline & Chongqing Iron \& Steel Company Limited. & 601005 \\
\hline & Xinjiang Joinworld Co., Ltd. & 600888 \\
\hline & Maanshan Iron And Steel Co., Ltd. & 600808 \\
\hline & Shandong Iron And Steel Company Ltd. & 600022 \\
\hline & Anyang Iron \& Steel Inc. & 600569 \\
\hline & Ji Lin Ji En Nickel Industry Co., Ltd. & 600432 \\
\hline
\end{tabular}


Table B2. Cont.

\begin{tabular}{|c|c|c|}
\hline Sectors & Company name & Stock code \\
\hline \multirow{43}{*}{$\begin{array}{l}\text { Metal } \\
\text { Fabrication }\end{array}$} & Shengda Mining Co., Ltd. & 000603 \\
\hline & Sichuan Western Resources Holding Co., Ltd. & 600139 \\
\hline & China Minmetals Rare Earth Co., Ltd. & 000831 \\
\hline & Jilin Liyuan Aluminum Co., Ltd. & 002501 \\
\hline & Yunnan Lincang Xinyuan Germanium Industrial Co., Ltd. & 002428 \\
\hline & Honyu Wear-Resistant New Materials Co., Ltd. & 300345 \\
\hline & Jiangsu Yulong Steel Pipe Co., Ltd. & 601028 \\
\hline & Ganfeng Lithium Co., Ltd. & 002460 \\
\hline & Jiangsu Asia-Pacific Light Alloy Technology Co., Ltd. & 002540 \\
\hline & Chongyi Zhangyuan Tungsten Co., Ltd. & 002378 \\
\hline & Shaanxi Ligeance Mineral Resources Co., Ltd. & 000697 \\
\hline & Suzhou Lopsking Aluminum Co., Ltd. & 002333 \\
\hline & Dongguan Eontec Co., Ltd. & 300328 \\
\hline & Shantou Wanshun Package Material Co., Ltd. & 300057 \\
\hline & Yinbang Clad Material Co., Ltd. & 300337 \\
\hline & Zhejiang Jiuli Hi-Tech Metals Co., Ltd. & 002318 \\
\hline & Shandong Lipeng Co., Ltd. & 002374 \\
\hline & Suzhou Yangtze New Materials Co., Ltd. & 002652 \\
\hline & Jinzhou New China Dragon Molybdenum Co., Ltd. & 603399 \\
\hline & Rising Nonferrous Metals Share Co., Ltd. & 600259 \\
\hline & Roshow Technology Co., Ltd. & 002617 \\
\hline & Henan Mingtai Al. Industrial Co., Ltd. & 601677 \\
\hline & Yechiu Metal Recycling (China) Ltd. & 601388 \\
\hline & Jiangsu Changbao Steeltube Co., Ltd. & 002478 \\
\hline & Xinjiang Bai Hua Cun Co., Ltd. & 600721 \\
\hline & Jiangxi Hengda Hi-Tech Co., Ltd. & 002591 \\
\hline & Jiangsu Shagang Co., Ltd. & 002075 \\
\hline & Daye Special Steel Co., Ltd. & 000708 \\
\hline & Maanshan Dingtai Rare Earth \& New Material Co., Ltd. & 002352 \\
\hline & Nanjing Yunhai Special Metals Co., Ltd. & 002182 \\
\hline & Ningbo Boway Alloy Material Co., Ltd. & 601137 \\
\hline & Juli Sling Co., Ltd. & 002342 \\
\hline & Guangdong Jingyi Metal Co., Ltd. & 002295 \\
\hline & Inner Mongolia Baotou Steel Union Co., Ltd. & 600010 \\
\hline & Xinjiang Ba Yi Iron And Steel Co., Ltd. & 600581 \\
\hline & Yunnan Copper Co., Ltd. & 000878 \\
\hline & Shandong Loften Aluminium Foil Co., Ltd. & 002379 \\
\hline & Luyin Investment Group Corp., Ltd. & 600784 \\
\hline & Nbtm New Materials Group Co., Ltd. & 600114 \\
\hline & Western Metal Materials Co. Ltd. & 002149 \\
\hline & Bengang Steel Plates Co., Ltd. & 000761 \\
\hline & Fushun Special Steel Co., Ltd. & 600399 \\
\hline & Tibet Summit Industry Co., Ltd. & 600338 \\
\hline
\end{tabular}


Table B2. Cont.

\begin{tabular}{|c|c|c|}
\hline Sectors & Company name & Stock code \\
\hline \multirow{27}{*}{$\begin{array}{l}\text { Metal } \\
\text { Fabrication }\end{array}$} & Jiangsu Fasten Company Limited. & 000890 \\
\hline & Ningxia Xinri Hengli Steel Wire Co., Ltd. & 600165 \\
\hline & Lingyuan Iron And Steel Co., Ltd. & 600231 \\
\hline & Anhui Jingcheng Copper Share Co., Ltd. & 002171 \\
\hline & Ningbo Fubang Jingye Group Co., Ltd. & 600768 \\
\hline & Xinyu Iron And Steel Co., Ltd. & 600782 \\
\hline & Beijing Shougang Co., Ltd. & 000959 \\
\hline & Hangzhou Iron \& Steel Co., Ltd. & 600126 \\
\hline & Jiangsu Alcha Aluminum Co., Ltd. & 002160 \\
\hline & Hunan Valin Steel Co., Ltd. & 000932 \\
\hline & China Tungsten And Hightech Materials Co., Ltd. & 000657 \\
\hline & Yunnan Luoping Zinc\&Electricity Co., Ltd. & 002114 \\
\hline & Sgis Songshan Co., Ltd. & 000717 \\
\hline & Zhuzhou Smelter Group Co., Ltd. & 600961 \\
\hline & Huludao Zinc Industry Co., Ltd. & 000751 \\
\hline & Sichuan Hongda Co., Ltd. & 600331 \\
\hline & Jingui Silver Industry Co., Ltd. & 002716 \\
\hline & Jilin Liyuan Precision Manufacturing Co., Ltd. & 002501 \\
\hline & Beijing Kingfe Culture Development Co., Ltd. & 002721 \\
\hline & Lofen Environmental Technology Co., Ltd. & 002379 \\
\hline & Laiwu Steel Corporation Co., Ltd. & 600102 \\
\hline & Shengyang Hejin Holding Co., Ltd. & 000633 \\
\hline & Hunan Corun New Energy Co., Ltd. & 600478 \\
\hline & Wasu Media Holding Co., Ltd. & 000156 \\
\hline & Guangdong Golden Horse Tourism Group Stock Co., Ltd. & 000602 \\
\hline & Guangzhou Guangri Stock Co., Ltd. & 600894 \\
\hline & Langfang Development Co., Ltd. & 600149 \\
\hline \multirow{12}{*}{$\begin{array}{l}\text { Oil } \\
\text { Producing } \\
\text { Equipment }\end{array}$} & China Oilfield Services Limited & 601808 \\
\hline & Offshore Oil Engineering Co., Ltd. & 600583 \\
\hline & Guanghui Energy Co., Ltd. & 600256 \\
\hline & Sichuan Renzhi Oilfield Technology Services Co., Ltd. & 002629 \\
\hline & Yantai Jereh Oilfield Services Group Co., Ltd. & 002353 \\
\hline & Landocean Energy Services Co., Ltd. & 300157 \\
\hline & China Oil Hbp Science \& Technology Co., Ltd. & 002554 \\
\hline & Gi Technologies (Beijing) Co., Ltd & 300309 \\
\hline & Tong Oil Tools Co., Ltd. & 300164 \\
\hline & Sino Geophysical Co., Ltd & 300191 \\
\hline & Kingdream Public Limited Company & 000852 \\
\hline & Lanzhou Haimo Technologies Co., Ltd. & 300084 \\
\hline
\end{tabular}


Table B2. Cont.

\begin{tabular}{|c|c|c|}
\hline Sectors & Company name & Stock code \\
\hline \multirow{9}{*}{ Oil and Gas } & China Petroleum \& Chemical Corporation & 600028 \\
\hline & PetroChina Company Limited & 601857 \\
\hline & Wintime Energy Co., Ltd. & 600157 \\
\hline & Oriental Energy Co., Ltd. & 002221 \\
\hline & Shenzhen Guangju Energy Co., Ltd. & 000096 \\
\hline & Shanghai Lonyer Fuels Co., Ltd. & 603003 \\
\hline & Xinjiang Zhundong Petroleum Technology Co., Ltd. & 002207 \\
\hline & Zhejianghaiyueco., Ltd & 600387 \\
\hline & Sinopec Shandong Taishan Petroleum Co., Ltd. & 000554 \\
\hline \multirow{33}{*}{$\begin{array}{l}\text { Gas and } \\
\text { Water } \\
\text { Related }\end{array}$} & Jiangsu Jiangnan Water Co., Ltd. & 601199 \\
\hline & Tianjin Capital Environmental Protection Group & \\
\hline & Company Limited & 600874 \\
\hline & Beijing Origin Water Technology Co., Ltd. & 300070 \\
\hline & Nanhai Development Co., Ltd. & 600323 \\
\hline & Shanghai Chengtou Holding Co., Ltd. & 600649 \\
\hline & Sound Environmental Resources Co., Ltd. & 000826 \\
\hline & Chengdu Xingrong Investment Co., Ltd. & 000598 \\
\hline & Shenzhen Gas Corporation Ltd. & 601139 \\
\hline & Tianjin Teda Co., Ltd. & 000652 \\
\hline & Heilongjiang Interchina Watertreatment Co., Ltd. & 600187 \\
\hline & Shanghai Dazhong Public Utilities(Group) Co., Ltd. & 600635 \\
\hline & Tieling Newcity Investment Holding Limited & 000809 \\
\hline & Luenmei Holding Co., Ltd & 600167 \\
\hline & Xinjiang Haoyuan Natural Gas Co., Ltd. & 002700 \\
\hline & Beijing Capitalco., Ltd. & 600008 \\
\hline & Liaoning Hongyang Energy Resource Invest Co., Ltd. & 600758 \\
\hline & Dongjiang Environmental Company Limited & 002672 \\
\hline & Yintai Resources Co., Ltd. & 000975 \\
\hline & Shaanxi Provincial Natural Gas Co., Ltd. & 002267 \\
\hline & Shanghai Safbon Water Service Co., Ltd. & 300262 \\
\hline & Jiangsu Welle Environmental Co., Ltd. & 300190 \\
\hline & Ningbo Thermal Power Co., Ltd. & 600982 \\
\hline & Guangdong Golden Dragon Development Inc. & 000712 \\
\hline & Nanjing Cec Environmental Protection Co., Ltd. & 300172 \\
\hline & Beijing Water Business Doctor Co., Ltd. & 300055 \\
\hline & Yonker Environmental Protection Co. Ltd. & 300187 \\
\hline & Tianjin Binhai Energy \& Development Co., Ltd. & 000695 \\
\hline & Zhongshan Public Utilities Group Co., Ltd. & 000685 \\
\hline & Chongqing Water Group Co., Ltd. & 601158 \\
\hline & Inner Mongolia Xingye Mining Co., Ltd & 000426 \\
\hline & Qianjiang Water Resources Development Co., Ltd. & 600283 \\
\hline & Guangzhou Devotion Thermal Technology Co., Ltd. & 300335 \\
\hline
\end{tabular}


Table B2. Cont.

\begin{tabular}{lll}
\hline Sectors & \multicolumn{1}{c}{ Company name } & Stock code \\
\hline & Shenyang Huitian Thermal Power Co., Ltd. & 000692 \\
& Jiangxi Hongcheng Waterworks Co., Ltd. & 600461 \\
Gas and & Wuhan Sanzhen Industry Holding Co., Ltd. & 600168 \\
Water & Zhongyuan Environment-Protection Co., Ltd. & 000544 \\
Related & Grandblue Environment Co., Ltd. & 600323 \\
& Nanjing Gaoke Co., Ltd. & 600064 \\
& Changchun Jinkai Co., Ltd. & 600215 \\
\hline
\end{tabular}

Notes: More details of these data could be provided if it is need.

\section{Conflicts of Interest}

The authors declare no conflict of interest.

\section{References}

1. Sun, L. China's mining output expanded nearly six times ten years. Available online: http://finance.eastmoney.com/news/1350,20121105257716331.html (accessed on 9 March 2014).

2. Iwata, H.; Okada, K. How does environmental performance affect financial performance? Evidence from Japanese manufacturing firms. Ecol. Econ. 2011, 70, 1691-1700.

3. Ackah-Baidoo, A. Fishing in troubled waters: Oil production, seaweed and community-level grievances in the Western Region of Ghana. Community Dev. J. 2013, 48, 406-420.

4. Ackah-Baidoo, A. Enclave development and "offshore Corporate Social Responsibility": Implications for oil-rich sub-Saharan Africa. Resour. Policy 2012, 37, 152-159.

5. Friedman, M. The social responsibility of business is to increase its profits. In Corporate Ethics and Corporate Governance; Springer: Heidelberg, Germany, 2007; pp. 173-178.

6. Moskowitz, M. Choosing socially responsible stocks. Bus. Soc. Rev. 1972, 1, 71-75.

7. Parket, I.R.; Eilbirt, H. The practice of business social responsibility: The underlying factors. Bus. Horiz. 1975, 18, 5-10.

8. Alexander, G.J.; Buchholz, R.A. Corporate Social Responsibility and stock market performance. Acad. Manag. J. 1978, 21, 479-486.

9. Abbott, W.F.; Monsen, R.J. On the measurement of Corporate Social Responsibility: Self-reported disclosures as a method of measuring corporate social involvement. Acad. Manag. J. 1979, 22, 501-515.

10. Vance, S.C. Are socially responsible corporations good investment risks? Manag. Rev. 1975, 64, 19-24.

11. Carroll, A.B.; Shabana, K.M. The Business Case for Corporate Social Responsibility: A Review of Concepts, Research and Practice. Int. J. Manag. Rev. 2010, 12, 85-105.

12. Williamson, O.E. The Economics of Discretionary Behavior: Managerial Objectives in a Theory of the Firm; Markham Publishing Company: Chicago, IL, USA, 1967.

13. Jensen, M.C.; Meckling, W.H. Theory of the firm: Managerial behavior, agency costs and ownership structure. J. Financ. Econ. 1976, 3, 305-360. 
14. Pava, M.L.; Krausz, J. The Association between Corporate Social Responsibility and Financial Performance: The Paradox of Social Cost. J. Bus. Ethics 1996, 15, 321-357.

15. Jensen, M.C. Value maximization, stakeholder theory, and the corporate objective function. Bus. Ethics. Q. 2002, 12, 235-256.

16. Blowfield, M.; Murray, A. Corporate Responsibility: A Critical Introduction; Oxford University Press: Oxford, UK, 2008.

17. Blowfield, M. Poverty's Case for Business: The Evidence, Misconceptions, Conceits and Deceit Surrounding the Business Case. Available online: http://bdsnetwork.cbs.dk/publications/ Working\%20Papers/bsd_working_paper_(paper5)_copy.pdf (accessed on 18 June 2014).

18. Blowfield, M.E.; Dolan, C. Fairtrade Facts and Fancies: What Kenyan Fairtrade Tea Tells us About Business' Role as Development Agent. J. Bus. Ethics 2010, 93, 143-162.

19. Frynas, J.G. Corporate Social Responsibility and international development: Critical assessment. Corp. Gov. 2008, 16, 274-281.

20. Frynas, J.G. The false developmental promise of Corporate Social Responsibility: Evidence from multinational oil companies. Int. Aff. 2005, 81, 581-598.

21. Aupperle, K.E.; Carroll, A.B.; Hatfield, J.D. An empirical examination of the relationship between Corporate Social Responsibility and profitability. Acad. Manag. J. 1985, 28, 446-463.

22. Bhunia, A. Association between Corporate Social Responsibility and firm financial performance: Empirical evidence from bombay stock exchange. Econ. Bull. 2012, 32, A20.

23. Fauzi, H.; Idris, K.M. The relationship of CSR and financial performance: New evidence from Indonesian companies. Issues Soc. Environ. Account. 2012, 3, 66-87.

24. Iqbal, N.; Ahmad, N.; Basheer, N.A.; Nadeem, M. Impact of Corporate Social Responsibility on Financial Performance of Corporations: Evidence from Pakistan. Int. J. Learn. Dev. 2012, 2, 107-118.

25. Tyagi, R. Impact of Corporate Social Responsibility on Financial Performance and Competitiveness of Business: A Study of Indian Firms. Ph.D. Thesis, Indian Institute of Technology, Roorkee, Indian, 2013.

26. Wu, M.-W.; Shen, C.-H. Corporate Social Responsibility in the Banking Industry: Motives and Financial Performance. J. Bank. Financ. 2013, 37, 3529-3547.

27. Parast, M.M.; Adams, S.G. Corporate Social Responsibility, benchmarking, and organizational performance in the petroleum industry: A quality management perspective. Int. J. Prod. Econ. 2012, 139, 447-458.

28. Govindarajan, V.; Amilan, S. An influence of CSR initiatives with financial performance: Evidence from petro-gas products industry in India. ACADEMICIA: Int. Multidiscip. Res. J. 2013, $3,1-27$.

29. Cowan, A.; Parzinger, M.; Welch, O.J.; Welch, S. Performance and Corporate Social Responsibility in the Information Technology Industry. J. Inf. Syst. Appl. Res. 2013, 7, 43-55.

30. Lee, S.; Singal, M.; Kang, K.H. The Corporate Social Responsibility-financial performance link in the US restaurant industry: Do economic conditions matter? Int. J. Hosp. Manag. 2012, 32, 2-10.

31. Lee, P.K.; Lau, A.K.; Cheng, T. Employee rights protection and financial performance. J. Bus. Res. 2013, 66, 1861-1869.

32. Wang, Z.; Sarkis, J. Investigating the relationship of sustainable supply chain management with Corporate Financial Performance. Int. J. Product. Perfor. Manag. 2013, 62, 871-888. 
33. Lioui, A.; Sharma, Z. Environmental Corporate Social Responsibility and financial performance: Disentangling direct and indirect effects. Ecol. Econ. 2012, 78, 100-111.

34. Sariannidis, N.; Zafeiriou, E.; Giannarakis, G.; Arabatzis, G. $\mathrm{CO}_{2}$ Emissions and Financial Performance of Socially Responsible Firms: An Empirical Survey. Bus. Strategy Environ. 2013, 22, 109-120.

35. Peng, C.-W.; Yang, M.-L. The Effect of Corporate Social Performance on Financial Performance: The Moderating Effect of Ownership Concentration. Available online: http://link.springer.com/ article/10.1007\%2Fs10551-013-1809-9\# (accessed on 18 June 2014).

36. Julian, S.D.; Ofori-Dankwa, J.C. Financial resource availability and Corporate Social Responsibility expenditures in a sub-saharan economy: The institutional difference hypothesis. Strateg. Manag. J. 2013, 34, 1314-1330.

37. Chen, G.-T. A Study of the Relationship between Corporate Social Responsibility and Financial Peformance: The Mediating Effect of R\&D. Master's Thesis, National Central University, Taiwan, 2013.

38. Raza, A.; Ilyas, M.I.; Rauf, R.; Qamar, R. Relationship between Corporate Social Responsibility (CSR) and Corporate Financial Performance (CFP): Literature review approach. Elixir Financ. Manag. 2012, 46, 8404-8409.

39. Sturdivant, F.D.; Ginter, J.L. Corporate Social Responsiveness: Management Attitudes and Economic Performance. Calif. Manag. Rev. 1977, 19, 30-39.

40. Hart, S.L.; Ahuja, G. Does it pay to be green? An empirical examination of the relationship between emission reduction and firm performance. Bus. Strategy Environ. 1996, 5, 30-37.

41. McGuire, J.B.; Sundgren, A.; Schneeweis, T. Corporate Social Responsibility and firm financial performance. Acad. Manag. J. 1988, 31, 854-872.

42. Scholtens, B. A note on the interaction between Corporate Social Responsibility and financial performance. Ecol. Econ. 2008, 68, 46-55.

43. Sharfman, M. The construct validity of the Kinder, Lydenberg \& Domini social performance ratings data. J. Bus. Ethics. 1996, 15, 287-296.

44. Roca, L.C.; Searcy, C. An analysis of indicators disclosed in corporate sustainability reports. J. Clean. Prod. 2012, 20, 103-118.

45. Álvarez, M.; Moreno, A.; Mataix, C. The analytic hierarchy process to support decision-making processes in infrastructure projects with social impact. Total Q. Manag. Bus. Excell. 2013, 24, 596-606.

46. Zhao, Z.-Y.; Zhao, X.-J.; Davidson, K.; Zuo, J. A Corporate Social Responsibility indicator system for construction enterprises. J. Clean. Prod. 2012, 29, 277-289.

47. Hilson, G. Corporate Social Responsibility in the extractive industries: Experiences from developing countries. Resour. Policy 2012, 37, 131-137.

48. HEXUN. Stocks financial database (2010, 2011, 2012). Available online: http://stockdata.stock.hexun.com/2008en/cwbl.aspx?stockid=002155 (accessed on 9 March 2014).

(C) 2014 by the authors; licensee MDPI, Basel, Switzerland. This article is an open access article distributed under the terms and conditions of the Creative Commons Attribution license (http://creativecommons.org/licenses/by/3.0/). 